\title{
KNOWLEDGE TRANSFER, KNOWLEDGE ACQUISITION AND QUALIFICATIONS IN THE CONTEXT OF RURAL DEVELOPMENT IN POLAND
}

\author{
Jarosław Greser ${ }^{1}$, Ryszard Kamiński ${ }^{2}$, Piotr Klatta ${ }^{3}$, Wojciech Knieć ${ }^{4}$, Jonatan \\ Martinez-Perez ${ }^{5}$, Anna Sitek ${ }^{6}$, Anthony Wagstaff ${ }^{7}$
}

\footnotetext{
1 Jarosław Greser, PhD, Adam Mickiewicz University Poland, email: greser@amu.edu.pl, ORCID: 0000-0002-10216142

${ }^{2}$ Ryszard Kamiński, PhD, Polish Academy of Sciences, Institute for Rural Development and Agriculture, Warszawa, Poland, e-mail: r.kaminski@pro.onet.pl, ORCID: 0000-0001-5110-8300

${ }_{3}^{3}$ Piotr Klatta, PhD, Educational Research Institute, Warszawa, Poland, e-mail: p.klatta@ibe.edu.pl

${ }^{4}$ Wojciech Knieć, Nicolaus Copernicus University, Toruń, Poland, e-mail: kniec@umk.pl, ORCID: 0000-0002-55003749

${ }^{5}$ Jonatan Martinez-Perez, MS, Spanish Royal Physics Society, Complutense University of Madrid, Spain, e-mail: jmp.ootb@gmail.com, ORCID: 0000-0003-1398-5032

${ }^{6}$ Anna Sitek, PhD, Center of Civic Initiatives, Toruń, Poland and Educational Research Institute, Warszawa, Poland, email: ania-sitek@wp.pl

7 Anthony Wagstaff, MD DAvMed PhD MBA, Adjunct Professor, Institute of Health and Society, University of Oslo, Norway, e-mail: anthony.wagstaff@flymed.uio.no
} 
Abstract: The aim of this study is to analyse the knowledge acquisition and transfer system in rural Poland, in comparison with nonrural areas. In addition, to determine the importance of market qualifications and the effects that the Integrated Qualification System can have in the rural areas. This study shows that life in the countryside is becoming more diverse and agriculture is no longer the main source of income because the share of income from non-agricultural activities is increasing. This is linked to the fact that rural areas have become more attractive for the development of non-agricultural jobs, which in turn is associated with the need not only to raise, but also to confirm qualifications acquired in everyday activities. The conducted analysis shows that acquisition and transfer of knowledge can come from two different platforms, individual and supralocal. These platforms work in two totally different ways. Our analysis also shows a gap between formal and non-formal or informal education in relation to the rural areas' needs. This gap can be bridged by using the Integrated Qualification System. Like a bidirectional tool, this system works on the one hand confirming acquired skills and knowledge, and on the other hand incorporating and updating the formal education system with non-formal or informal knowledge. The recognition of informal or non-formal qualifications has an important role in sustainable development and improving quality of life of rural areas. The article refers to the issue of qualifications of rural population, it is difficult to consider this issue in isolation from rural areas. The aim of the authors was to focus on the analysis of the issue of qualifications among people directly related to the countryside. The authors do not refer only to farmers, nevertheless, the reference to this social group finds its justification in the studies that are cited.

Keywords: rural areas, knowledge transfer, knowledge acquisition, market qualifications, Integrated Qualification System, non-formal education, informal education, Poland

\section{Highlights}

- Agriculture is no longer the main source of income in rural Poland, as life has become more diverse

- Rural areas have become more attractive for the development of non-agricultural jobs

- The increased need for non-agricultural jobs poses a new need for confirming qualifications acquired in everyday activities

- The Integrated Qualification System can fill the gap between formal and non-formal or informal qualifications

\section{Introduction}

For many years we have been observing dynamic change processes taking place in rural areas. As a result of these changes, life in the countryside is becoming more diverse and agriculture is no longer the main source of income.

With the development of more competitive markets and rapidly changing needs, the level of education and qualification becomes particularly important (Sawicka, 2001). This is reflected in emerging tendencies to independently acquire knowledge, skills and competences. Lifelong learning is becoming an indispensable tool for achieving a sustainable society (Stefanel, 2012: 4510). It fulfills a vital function in supporting sustainable development, particularly in rural areas. In these areas, the need for intangible resources is increasing, in turn also influencing their further development (Gabińska, 2016: 64). In addition, customers are now more demanding, looking for instance, looking for ecological products, which require a higher level of knowledge to produce. For all this, knowledge, skills and competencies acquired through formal, informal and non-formal 
education ${ }^{8}$ are considered some of the most important socio-economic factors generating change in the countryside (Wójcik, 2017: 159). Thus, they prepare inhabitants of rural areas to affront changes, allowing the implementation of new ideas, practices and technologies (Evans, 2009: 1). This situation makes rural areas more attractive for the development of non-agricultural jobs, which in turn is associated with the need not only to raise, but also to confirm qualifications acquired in everyday activities.

The above causes rural areas in Poland to be under an increasing and intersecting need for further research. The actors, the uses, the challenges and the way rural people are obtaining knowledge are all changing rapidly. This presents us with new research questions regarding the qualifications of rural people.

The outlined way of thinking, and the changes that have taken place in the Polish countryside, including knowledge acquisition and use, have had a significant impact on the interest in this topic. The fact that there are few studies and research on learning outcomes acquired in an informal or non-formal way, as well as a lack of a deeper understanding of the role of market qualifications $^{9}$, which are one of the pillars of the Integrated Qualification System ${ }^{10}$, was the driving force for investigating this topic.

The inspiration for the article was both existing and evoked materials. Most recently, the research entitled "Analysis of competences and qualifications in the agricultural sector" implemented in the period from December 2018 to March 2019 at the Educational Research Institute (IBE) added important insight. This analysis was part of the work on the Sectoral Qualification Framework for Agriculture, integrated in the project "Supporting the implementation of the second stage of the implementation of the Integrated Qualifications System at the level of central administration and institutions granting qualifications and ensuring the quality of awarding qualifications".

The transfer of knowledge in agriculture was not originally the area of interest of the research team. The aim of the research was to determine, thanks to the analysis of existing data and qualitative research, the existing competences in Polish agriculture, thanks to the analysis of existing data and qualitative research. The adopted methodology was to allow the capturing of a number of cases of differentiated competences, and possibly creating a complete set of them.

\section{Methods and results}

IDI interviews were carried out with the use of additional sampling criteria, which were: farm size and agricultural specialization. A farm in the study was defined as a unit that carries out activities related to the cultivation of plants, and/or the rearing or breeding of animals, regardless of the legal form of operation (including for private use).

\footnotetext{
8 In this article, through formal education, otherwise known as school education, consisting of education within the institutionalized education system. An important element of formal education is the opportunity to obtain a specific level of education or formal entitlements obliging the employer to recognize them. On the other hand, non-formal education is understood as educational activity situated outside the formal education system, i.e. courses, seminars, lectures, fan clubs, various forms of training, postgraduate studies, etc. In turn, informal education is understood by the authors as lifelong learning in the sense of a lifelong process. This education enables the learner to acquire knowledge, attitudes, values and skills in the course of their own experiences. This process can often be made aware of by an individual to a limited extent (Fraczak, 2018: 106).

${ }^{9}$ Market qualifications - as the name says - are the answer to market needs. Any entity that decides that a given qualification is needed may submit it to the IQS. These are qualifications not regulated by law. Market qualifications are qualifications developed by various circles (social organizations, associations, corporations or other entities) on the basis of their experience. The word "market" means in this case that the qualifications are developed and operate on a "free market" of qualifications.

10 The Integrated Qualifications System is an important tool of the lifelong learning policy, a solution aimed at increasing the level of human capital in Poland by describing, organizing and collecting various qualifications in one register the Integrated Qualifications Register. ZSK defines the rules and standards for confirming qualifications; makes it easier for potential employees to certify their competences, even if they do not have specific education; increases the chances of getting a job at home and abroad, thanks to international recognition; helps employers recognize the value of an employee. The system was introduced by the Act on the Integrated Qualifications System of 22 December 2015 (Journal of Laws No. 2016 item 64), the external rationale for its creation was the recommendation of the European Parliament and the Council on the qualifications framework, which was adopted by almost all European countries.
} 
Although, as mentioned above, the purpose of the research was not issues related to knowledge transfer, 60 individual in-depth interviews (IDI) were carried out (see Table 1), containing questions with relevant information on such issues ${ }^{11}$.

Tab 1. IDI research. Source: Own study based on research carried out by the Educational Research Institute.

\begin{tabular}{|c|c|c|c|}
\hline Research technique & $\begin{array}{c}\text { Group of } \\
\text { respondents }\end{array}$ & Location & Number \\
\hline \multirow{3}{*}{$\begin{array}{c}\text { Individual } \\
\text { in-depth interview (IDI) }\end{array}$} & \multirow{2}{*}{ Farm staff } & Region: Pomorze and Mazury & 15 IDI \\
\cline { 3 - 4 } & & Region: Wielkopolska and Śląsk & 15 IDI \\
\cline { 3 - 4 } & & Region: Mazowsze and Podlasie & 15 IDI \\
\cline { 3 - 4 } & & Region: Małopolska and Pogórze & 15 IDI \\
\hline
\end{tabular}

Of the 60 people participating in the interviews, 34 identified themselves as working in small family farms, most often employing 2-4 people, and 26 in large farms employing 10 to over 50 people. Thus, the study over-represented large farms, which resulted from the desire to include farms in each region with different characteristics regarding the size and number of people working in them.

Within small family farms, almost all IDI participants declared formal agricultural education at the level of vocational school, technical college or university. 6 out of 34 respondents declared formal non-agricultural education, which was supplemented with postgraduate studies in agriculture or the agricultural qualification course R3.

It should be noted that the obtained results, although they cannot be generalized, present an opportunity to view knowledge transfer processes occurring among the rural population. For this reason, they can form the basis for building hypotheses related to the discussed issue and planning further research.

\section{Discussion}

Methods and processes for transferring knowledge of rural residents has not been a leading research topic so far. When summarizing the research areas of Polish rural sociology, Andrzej Kaleta does not include education or knowledge transfer among them (Kaleta, 2013: 33-47). This does not mean, however, that this issue has not been raised. Such analyses have been performed previously, mainly concerning general education in the context of the transformation of the Polish countryside after 1990.

Most of the work dealing with the discussed subject previously, was directed at the development of social capital in the rural environment, involving human capital of rural inhabitants (Herbst, 2004; Zdrojewska, 2009; Mikiewicz, 2008). In the works created in the first period of political transformation, which strongly affected rural communities, the main findings were a significantly lower percentage of educated people living in the countryside than in urbanized areas, a strong current attachment to tradition and reluctance to change, and farmers being passive in view of the changes taking place in the country at that time (Szafraniec, 1998: 315; Halamska, 2006: 524).

After Poland's accession to the EU in 2004, the issue of knowledge transfer in the countryside was raised in studies on the creation of new, ecological forms of farming. There were also studies supported by rural development policy of rural communities, local communities and NGOs

\footnotetext{
11 These questions were related to issues such as: education, seniority in agriculture, ways of obtaining knowledge needed for work on the farm, difficulties encountered in performing tasks related to farm work, unique skills, knowledge acquired in recent years, the use of new technologies and innovative solutions at work.
} 
carrying out certain educational activities, or activities in "learning organizations" (Knieć, 2010; Fedyszak-Radziejowska, 2012; Jewtuchowicz, 2013; Będzik, 2014).

The issues of education and knowledge transfer in agriculture were also an area of interest for representatives of geographic and economic sciences dealing with development strategies and area planning. Results from this research showed a significant relationship between the level of education of farmers and the size of farms (Klepacki, 2005: 47-57; Woźniak, 2016: 57-67; Kamińska 2016: 9-30; Gwiaździńska-Goraj: 2015: 51-63). Many studies focused on presenting the financial, physical and social barriers existing in Poland regarding farmers' access to sources of formal education. These barriers were seen as important reasons for the low level of agricultural education (Floriańczyk, 2012: 45-56; Czapiewski, 2010: 24-36). The authors pointed to the importance of knowledge, skills and education as the endogenous capital of rural development. They also found issues related to inequalities in access to knowledge resources, and analyzed changes in the aspects of farmers' education (Czapiewski, 2014: 337-359; Czapiewski, 2016: 9-27).

At the same time, several research projects carried out by a team of Torun sociologists together with agricultural advisory centers showed the key importance of access to knowledge and modification of agricultural qualifications for creating appropriate adaptation strategies for Polish farms. Their findings were important in order to support instruments offered to Poland under the Common Agricultural Policy (Knieć, 2012). The studies revealed the potential of informal professional qualifications commonly found among farmers and their family members. This, in turn, was the result of "forced resourcefulness" in the face of the educational marginalization of the Polish countryside and - perhaps more importantly - the widespread depreciation within the farming community of the importance of formal education (Knieć, 2003).

Interest in non-agricultural activity of members of agricultural families certainly has its sources in multi-profession. Durand and van Huylenbroeck (2003) defined pluriactivity as a combination of agricultural and non-agricultural activities performed by farmers or members of the farmer's household. Bryden and Fuller (1988: 11) point out in a report on multitasking that "originally many authors wrote about running part-time farming, while these issues are usually more complex and there are many different multitasking variants". The quoted authors state that a part-time farmer's work is often assessed as inefficient, or not as good, as farmers working "full-time". However, because a farm in European realities means more than just a place of food production, many members of agricultural families do not treat work outside the farm as a personal failure, but as a choice of a new career path or simply a source of additional income (Bryder, 1998: 12). Jervell points out that the spreading phenomenon of multi-activity in agricultural families leads to a change from the family farm model to the model of a farm with one person working in agriculture (Jervell 1999: 104). Bacon and Brewin (2008: 11) emphasize that the phenomenon of taking up work outside the farm primarily concerns farmers' wives. They emphasize that working wives ensure the continuation of the existence (functioning) of many farms. Kinsella writes about farmers' multi-activity in a similar way, as a strategy for the survival of an agricultural family (2000: 487) ${ }^{12}$. Renting and Heinonen (2008: 380) drew attention to the need for a broader look at the benefits of multi-profession and farm diversification in the form of many public goods offered in such an agricultural model.

In recent years, we have seen interesting publications related to the planning of rural development; addressing the general transfer of knowledge, including the degree of access to the Internet as a source of knowledge and a factor in improving rural development in Poland (Janc, 2014: 195-218). Agricultural magazines and periodicals have also been analyzed (Solon, 2014: 273-291). These works are particularly valuable because they provide unique data pertaining to this research area. However, they treat the internet and the agricultural press primarily as a source of knowledge supporting resources built on the foundation of yet very weak, formal agricultural education, according to the authors.

\footnotetext{
12 Rogers (1988: 189) reportS that in the USA between 1960 and 1980 the number of rural women working outside the home doubled. At the same time, in 1979, $44 \%$ of women from farms and $48 \%$ of rural women worked outside the home, which was only a slightly lower percentage than for women from "urban" families.
} 
The World Bank defined the Agricultural Knowledge and Information System as an interrelated network of systemic relations between people and institutions, which not only generates knowledge and information, but also transfers and uses them in practice (Kania, 2007: 45-460; Sikorska-Wolak, 2014: 12). According to this approach, farmers use a very wide spectrum of sources of knowledge, such as agricultural schools, agricultural advisory centers, chambers of agriculture, or private advisory offices. Sources of knowledge are also companies selling production means, companies purchasing agricultural products, ministries of agriculture, protection environment, finance, universities and research institutes, government agencies, banks, foundations, non-governmental organizations, Internet, press, radio, television, and other farmers (Skorska-Wolak, 2014: 13).

This idea corresponds to the concept of a networked rural development, a concept proposed some 20 years ago by Jonathon Murdoch. He proposed that rural development consisted of both horizontal and vertical networks that managed the flow of knowledge and resources between and into rural areas. These networks of knowledge exchange, based mainly on non-governmental organizations (mainly semi-formal) and informal social institutions (neighborhood ties, social circles, power networks) had and have the character of non-system structures. They function outside the formal education system, based on the mechanisms of diffusion of innovation through trust networks. It is not surprising, therefore, that despite the extensive vocational training system of farmers in Poland in the early 21 st century, still over $60 \%$ of farmers did not have formal agricultural education (Bański, 2010) ${ }^{13}$. However, some may consider Bański's data to be outdated. Currently, many more individual farmers have formal agricultural education or agricultural qualification. Taking this point of view, it is possible to hypothesize that an increase in the level of agricultural education is forced by gradual changes in agricultural land regulations. In the current Polish legal system, only an individual farmer can be a buyer of agricultural real estate. And an individual farmer is "a physical person who is the owner, perpetual usufructuary, independent owner or tenant of agricultural real estate, whose total area of arable land does not exceed 300 ha, possessing agricultural qualifications and residing in the commune for at least 5 years, in the area where one of the agricultural properties forming part of the agricultural holding is situated and who personally runs the holding during that period". The same act sets out the education that will be considered as confirmation of the agricultural qualifications held by the individual farmer, which is:

(a) basic vocational or technical agricultural education

(b) qualifying title or professional title or professional title of a master in a profession useful for conducting the agricultural activity and has at least 3 years of work experience in agriculture,

(c) higher education other than agricultural and has at least 3 years of work experience in agriculture or higher education other than agriculture and completed post-graduate studies in agriculture-related, or secondary or secondary non-agricultural education and has at least 3 years seniority in agriculture,

(d) primary, lower secondary, basic vocational or basic vocational education other than agriculture and has at least 5 years of employment in agriculture.

As a result of these regulations, nowadays, if someone wants to buy any agricultural real estate, they must have the qualifications specified in the act. This is probably why the number of farmers with formal agricultural education, or agricultural qualification, has increased in recent years. That is why in recent years, the number of farmers with formal agricultural education or agricultural qualifications has increased. Although agricultural qualifications mainly serve to meet legal requirements, they also provide the basic knowledge and competence necessary to run a farm. In order to be successful, however, farmers need far more knowledge and skills than they receive in formal education.

This also applies to the processes of diversification of agricultural incomes. For example, the first agritourism initiatives in Poland were the result of a non-formal acquisition of competences based

\footnotetext{
13 Bański's data about the occurrence level of formal agricultural education of polish farmers may be outdated. Currently, many more individual farmers have formal agricultural education or agricultural qualification (due to legal changes, individual farmers must have agricultural qualifications).
} 
on their own experience and observations, rather than the knowledge acquired formally (Hałasiewicz, Kaleta, 2000). From this perspective, the level, or rather the balance of social capital, is crucial for the free flow of knowledge to rural areas. In the research by Goszczyński, Knieć and Obracht-Prondzyński, on the capital of the Pomeranian village, it was shown how high bonding capital, accompanied by a low level of bridging capital, leads to the production and duration of rural local communities self-isolating from external influences, closed from the inflow of external knowledge and entangled in clientelistic and familial social systems that inhibit local development (Goszczyński, Knieć, Obracht-Prondzyński, 2013). And vice versa: Local communities, with the social capital described by Woolcock (1999) and rooted in the normative basis of openness, built the foundations for cooperation and exchange of knowledge. They also built (which is probably the most important) various channels for acquiring knowledge and competences from institutions and groups outside them.

Such a broad approach to the sources of agricultural knowledge and the inclusion of farmers themselves as producers allows a different approach to the issue of knowledge transfer in the sector than before. In this approach, we look at education as a tool of promoting sustainable development and improving the capacity of people to address environmental and development issues [in: Evans, 2009: 44]. Also, as a process which is pursued throughout life: learning which is flexible, diverse and available at different times and in different places (beyond: Głębocka, 2015: 51).

\section{General discussion - knowledge acquisition by rural people}

Formal education can be described as know-what (knowledge of facts) and know-why (knowledge of the causality of nature, society). Knowledge available from books and other sources become outdated quickly due to the dynamics of changes taking place (Lundvall, 1996: 4-6) ${ }^{14}$. Apart from such formal education, there are two platforms of gaining knowledge and qualification in the countryside: individual and supralocal.

The first, individual platform, consists of human cooperation in making crops grow and animal breeding, resulting from many years of socialization and experience regarding the environment. Knowledge results from daily activities, observation of other people's work, exchange of views and experiences with members of the local community (Wójcik, 2017: 159), and daily observation of activities performed by older people (Wójcik, 2017: 164). Until recently, knowledge obtained from leaders was easy to obtain. It combines know-how (it relates to the ability to do something) and know-who (thanks to the possibility to identify people due to the specificity of their actions; it is based on the social ability to cooperate and communicate) (Lundvall, 1996: 4-6). This resulted from the specificity of rural local communities, i.e. the coexistence of residents within a small community (Stefanel, 2012: 4509).

The second, i.e. the supralocal platform, is related to the transfer of knowledge from outside the agricultural sector. This manifests itself primarily in those rural regions of the country where the share of jobs outside agriculture is growing rapidly, and results in a wide range of professions and qualifications. It helps rural people acquire skills necessary to enter the labor market or secure their position in the labor market, or it may help them re-orient occupations or careers (Evans, 2009: 45). It should be noted that in the case of traditional rural communities, knowledge transfer played a secondary role due to the points described above. However, modern technologies and innovative solutions are priorities. One of the most important reasons for this is the fundamental role of knowledge as capital in the information society. This leads to the phenomenon of the codification of knowledge, which becomes the object of turnover and value building. This

\footnotetext{
${ }^{14}$ In that place, it is worth to mention, that persons participating in IDI assessed formal agricultural education negatively, and it should be emphasized that opinions of this type were not expressed by persons with higher education. In conversations with the researchers conducting the study, the outdated education system was criticized, its maladaptation to modern conditions and technologies, and the poor usefulness of acquired knowledge in practical management. This is perfectly reflected by one of the statements: in different schools this level is really very poor when it comes to teaching. Methods from 30 or 40 years ago are promoted, which have now become a thing of the past in the current world and yet it is repeated all the time. This is a very bad phenomenon.
} 
process also includes issues related to rural areas, including traditional knowledge (Thornberry, 2002).

In practice, knowledge transfer may have a different socio-economic nature, but its purpose is to enable resource trading (Sieńczyło-Chlabicz, 2019: 314). Therefore, both knowledge acquired individually and supra-locally, embodied by market qualifications, are key factors enabling adaptation, and as such, are important assets communities possess in the face of change.

The qualifications of the rural population are traditionally associated with the profile of their workplace. This situation means that farmers usually are associated with a low level of education. Such beliefs can be associated with the fact that rural (strongly related to agriculture) labor markets have not yet shown a high demand for highly qualified employees (Janc, 2016: 9-10). As a result, farmers have rarely decided to supplement their knowledge. It is worth noting that the dynamically changing environment, generating the need to use modern technologies, is a challenge in the area of knowledge dissemination (Florianczyk, 2012: 47). Extensive activities have been carried out in Norway and other Scandinavian countries regarding validation of farmers' informal competences, which were then verified through external vocational examinations and, if necessary, supplemented with qualification courses (McHenry, 2002: 7087). Thomas Nilsen describes the Norwegian experience in the field of agriculture, among others, in the development of the Euro-validation project. Report for Norway "from $2006^{15}$.

In many countries, the basis for the process of vocational reorientation is confirmation of competences, e.g. according to the Dutch model ${ }^{16}$ "Valuation of Prior Learning" confirming competences previously acquired in various ways in both the education process and professional experience, for example, in the profession of a farmer. An additional element of such understood reorientation is the so-called "Recognition", which is a specific confirmation of these competences as part of professional exams. Patrick Werquin writes about this in the OECD study "Recognising Non-Formal and Informal Learning: Outcomes, Policies and Practices" (2010). Thus, in the whole process, the most important are not vocational courses, but consultancy work with individual members of the farmer's family, determining possible further career paths and confirming their competences (which may or may not be preceded by a short professional course) (Kamiński, 2015).

Taking into account the specificity of rural areas, creation of agricultural knowledge has so far often been carried out in isolation from the needs and expectations of its recipients (Kania, 2011: 27). This made it difficult for people taking care of the farm (or planning to take care of the farm) to have opportunities to gain qualifications that could help them in their daily work (Bański, 2003: 80 ), also since practical skills played such an important role. Hence, the level of qualifications of the rural population does not depend only on the education acquired in the school cycle. Training in adulthood is also important (Mossakowska, 2009: 10). Education in the non-formal system is currently gaining importance because continuous improvement of qualifications and skills becomes a necessity [in: Jaworski, 2018: 30] in the context of the spread of new ways of farming, often based on modern technologies. Sustainable development of rural areas largely depends on the ability to absorb innovation, acquire new knowledge, and skillful management of development processes (Kulej-Dudek, 2016: 168). On the other hand, in a situation of a widespread shortage of qualified labour force on the Polish labour market, labour market institutions are ready to implement bold strategies for recognizing and validating informal qualifications, particularly in rural areas (Knieć, Pluskota, 2018). This is very important in view of the fact that, for many years, rural labor market researchers have shown (Evans, 2009; Knieć, Pluskota 2018) that the recognized informal qualifications of the agricultural population coincide with deficient qualifications in other parts of the Polish labor market (construction, vehicle mechanics, hydraulics). Finally, it is important that the rural population, including farmers, are more and more aware of qualifications they have acquired outside the formal education system, and are also

\footnotetext{
$15 \mathrm{http} / /$ www.euracademy.org/eurovalidation/index.php?option=com_content\&task=view\&id=41\&ltemid, available on 4.12.2011

$16 \mathrm{http}: / /$ www.euracademy.org/eurovalidation/index.php?option=com_content\&task=view\&id=41\&, available on 4.12.2011 r.
} 
increasingly willing (with the participation of specialized vocational activation instruments) to reach for them (The European Committee of the Regions 2014; Knieć, 2018).

According to the results of research on lifelong learning, carried out in 2011 among people aged 25-64, non-formal and informal education plays a dominant role in Poland. Much experience in the field of vocational reorientation of farmers and their family members was collected and described in the period 2008-2015 in the Kuyavian-Pomeranian Voivodeship (Kamiński, Sass, 2013 and 2014; Kamiński 2011). This way of raising their competences was declared by $29 \%$ and $60 \%$ of respondents, respectively. For rural areas this ratio was $22 \%$ and $70 \%$, respectively (see Table $2^{17}$ ) (Głębocka, 2015: 56). Moreover, people living in the cities learn more often than people from rural areas. In the cities the rate of improving skills amounts to $14.6 \%$ and in the rural areas 11.8\% (Głębocka, 2015: 56).

Tab 2. People aged 25-64 years by participation in formal learning, non-formal and informal learning in Poland in 2011. Source: Głębocka, K., 2015. The importance of lifelong learning in XXI century. In: Central European Review of Economies and Finance, Vol. 8, No. 2, p. 56

\begin{tabular}{|c|c|c|c|c|}
\hline & Total in 1 000 & $\begin{array}{c}\text { Formal } \\
\text { learning } \%\end{array}$ & $\begin{array}{c}\text { Informal } \\
\text { learning } \%\end{array}$ & $\begin{array}{c}\text { Non-formal } \\
\text { learning } \%\end{array}$ \\
\hline Total & 22299 & 21 & 29 & 60 \\
\hline Cities areas & 13931 & 25 & 33 & 54 \\
\hline Rural areas & 8367 & 14 & 22 & 70 \\
\hline
\end{tabular}

It is worth noting that, year by year, there is an increasing number of people who participate in non-formal and informal education. This is indicated by data from the statistical office for 2016, according to which over $21 \%$ of the population participated in various forms of non-formal education and $31 \%$ in forms of informal education. For rural areas these rates were $15 \%$ and $33 \%$, respectively (while for urban areas, it was 25 and 66) (Jaworski, 2018: 32, 53).

Despite the relatively high percentage of people declaring participation in various forms of informal education, the value of the adult education index significantly differs from the average for $28 \mathrm{EU}$ countries. The average value of non-formal training for 28 countries of EU is $40.8 \%$. Poland is one of the countries with the lowest ratio, the highest is found in the Nordic countries (Głębocka 2015: 56). Table 3 illustrates this in more detail.

Nevertheless, rural residents, in comparison with urban residents, declare greater demand for certificates confirming specific qualifications. This especially applies to qualifications acquired through non-formal education. People participating in non-formal education in order to achieve learning outcomes most often use the Internet, books and magazines or help from other people. Respectively, $85 \%, 80 \%$ and $47 \%$ of people participating in non-formal education have indicated these methods of acquiring knowledge, skills and competences. For rural areas, this indicator was at the level of $81 \%, 78 \%$ and $47 \%$ respectively (Jaworski, 2018: 48-53).

\footnotetext{
17 In table figures do not add up to totals, because one person can participate simultaneously in several forms of training.
} 
Tab 3. Participation of people aged 25-64 years in lifelong learning in the EU, 2011. Source: Głębocka, K., 2015. The importance of lifelong learning in XXI century. In: Central European Review of Economies and Finance, Vol. 8, No. 2, p. 57

\begin{tabular}{|c|c|c|c|}
\hline Country & Lifelong learning $\%$ & Formal training $\%$ & Non-formal training $\%$ \\
\hline Austria & $14 \%$ & $6 \%$ & $46 \%$ \\
\hline Belgium & $7 \%$ & $7 \%$ & $33 \%$ \\
\hline Bulgaria & $2 \%$ & $2 \%$ & $24 \%$ \\
\hline Croatia & $3 \%$ & $5 \%$ & $18 \%$ \\
\hline Cyprus & $7 \%$ & $4 \%$ & $41 \%$ \\
\hline Czech Republic & $9 \%$ & $4 \%$ & $35 \%$ \\
\hline Denmark & $31 \%$ & $13 \%$ & $53 \%$ \\
\hline Estonia & $12 \%$ & $7 \%$ & $48 \%$ \\
\hline Finland & $25 \%$ & $10 \%$ & $51 \%$ \\
\hline France & $18 \%$ & $6 \%$ & $49 \%$ \\
\hline Greece & $3 \%$ & $3 \%$ & $10 \%$ \\
\hline Spain & $10 \%$ & $7 \%$ & $34 \%$ \\
\hline Holland & $18 \%$ & $12 \%$ & $55 \%$ \\
\hline Ireland & $7 \%$ & - & - \\
\hline Lithuania & $5 \%$ & $4 \%$ & $26 \%$ \\
\hline Luxembourg & $14 \%$ & $10 \%$ & $68 \%$ \\
\hline Latvia & $6 \%$ & $4 \%$ & $31 \%$ \\
\hline Malta & $8 \%$ & $4 \%$ & $34 \%$ \\
\hline Germany & $8 \%$ & $3 \%$ & $48 \%$ \\
\hline Poland & $4 \%$ & $5 \%$ & $21 \%$ \\
\hline Portugal & $10 \%$ & $10 \%$ & $40 \%$ \\
\hline Romania & $2 \%$ & $1 \%$ & $7 \%$ \\
\hline Slovak Republic & $3 \%$ & $6 \%$ & $38 \%$ \\
\hline Slovenia & $12 \%$ & $2 \%$ & $35 \%$ \\
\hline Sweden & $29 \%$ & $14 \%$ & $67 \%$ \\
\hline Hungary & $3 \%$ & $7 \%$ & $38 \%$ \\
\hline United Kingdom & $16 \%$ & $15 \%$ & $40 \%$ \\
\hline Italy & $8 \%$ & $3 \%$ & $34 \%$ \\
\hline
\end{tabular}

This is also confirmed by research carried out by the Educational Research Institute, which allowed the identification of a number of key qualifications for rural areas - from the respondents' point of view. Respondents identified over 90 qualifications, some of which were considered deficit and some as future qualifications (look at Table 4). 
Tab 4. Key competences for the agricultural sector. Source: Own study based on research carried out by the Educational Research Institute included in Markowska, M., Klatta, P., Danielewicz, M., Stankowska, J. 2019. Analysis of competences in the agricultural sector - Report. Warsaw: The Educational Research Institute (IBE)

\begin{tabular}{|c|c|c|c|}
\hline & Category & $\begin{array}{c}\text { Number } \\
\text { of competences }\end{array}$ & $\begin{array}{c}\text { Number } \\
\text { of strategic competences }\end{array}$ \\
\hline 1. & $\begin{array}{c}\text { functioning of the sector and } \\
\text { the market }\end{array}$ & 3 (3 deficit) & 1 \\
\hline 2. & functioning in a legal environment & 5 (4 deficit, 1 upcoming) & 1 \\
\hline 3. & $\begin{array}{c}\text { functioning of the natural } \\
\text { environment }\end{array}$ & 2 (1 deficit, 1 upcoming) & \\
\hline 4. & other social competences & 14 (12 deficit, 4 upcoming) & 1 \\
\hline 5. & other skills & 24 (12 deficit, 15 upcoming) & 6 \\
\hline 6. & crossing & 4 (2 deficit, 4 upcoming) & \\
\hline 7. & fertilization & 1 (1 upcoming) & \\
\hline 8. & $\begin{array}{c}\text { storage of agricultural products and } \\
\text { internal transport }\end{array}$ & 9 (3 deficit, 7 upcoming) & 2 \\
\hline 9. & $\begin{array}{c}\text { use of vehicles, machines and } \\
\text { devices }\end{array}$ & 7 (2 deficit, 5 upcoming) & 1 \\
\hline 10. & $\begin{array}{l}\text { management and running of the } \\
\text { holding }\end{array}$ & 25 (12 deficit, 15 upcoming) & 7 \\
\hline
\end{tabular}

It seems that confirmed qualifications are central tools of improving employability and livelihood opportunities, reduce poverty, enhance productivity, and promote environmentally sustainable development. Market qualifications are considered as the main tool for increasing skills and employability of rural people. On the other hand, validation and certification of informally gained skills and knowledge would lead to substantial improvement on the field of qualifications deficits on rural labor market.

Continuous improvement of qualifications increases the effectiveness and transfer of knowledge to practice, necessary for improving work efficiency (Nadobnik, 2011: 16) and improving living conditions. It is worth noting that, in Poland, the importance of improving qualifications and continuous improvement of knowledge and skills is still not implemented (Adamowicz, 2005: 342). Therefore, the low level of qualifications of the rural population cannot be raised without the extensive development of adult education at all levels, including informal and course models (Gabińska, 2016: 65).

\section{Conclusions}

The conducted analysis shows that sharing knowledge has never been so important, because by knowledge exchange people are able to support the search for new ideas. Knowledge transfer/exchange helps to continue growing a sustainable rural area and also contributes to finding more of the long-term solutions that rural residents can offer to society. There is a gap between formal education and the real needs of rural people in terms of knowledge and competence. This gap, which does not match with the reality of current rural areas due to the fact that it is too theoretical and not very practical, can be bridged by the market qualification.

Currently, market qualifications, which are one of the key elements of the Integrated Qualifications System ${ }^{18}$, do not play a significant role and therefore have not been able to significantly change the living conditions of the people they are addressed to. Nevertheless, in the context of a lifelong

${ }^{18}$ From the beginning of the functioning of the Integrated Qualifications System, 305 applications for the inclusion of market qualifications have been submitted to the Integrated Qualifications Register, of which 59 qualifications have been included (33 qualifications have functioning status). During this period, 11 applications for the inclusion of qualifications were sent to the Minister of Agriculture and Rural Development, of which one was rejected, one passed, the remaining 9 are pending; description of those qualification are available on webpage https://www.gov.pl/web/rolnictwo/zintegrowany-system-kwalifikacji (data from November 14, 2019). 
learning process, in which the synergy of formal, non-formal and informal learning is emphasized, the issue of knowledge recognition, skills and social competences acquired through various paths, is meaningful (Matusiak, 2014: 65).

There is no doubt that the process of acquiring, accumulating and confirming qualifications allows individuals to function more efficiently in social space (at both macro, meso and micro levels), particularly in active search and taking up work. Market qualifications seem to be key to improving quality of life, reducing poverty, increasing productivity of rural residents and promoting sustainable rural development, and may build and stimulate the resilience of rural social systems. The Integrated Qualification System is a tool that can help people to officially confirm skills and knowledge acquired in the workplace, through courses, in everyday situations, or by self-study at home.

Finally, the recognition of these knowledge and skills by the Integrated Qualification System helps the formal education system to acquire, incorporate and update all the non-formal knowledge generated in the rural areas through daily work. This generates a virtuous circle, thus producing a better adaptation to the real conditions of the formal educational

\section{Academic references}

[1] Adamowicz, M. \& Nowak, A. (2005). Szkoły wiejskie w kontekście kreowania kapitału ludzkiego. Nierówności Społeczne a Wzrost Gospodarczy, 6, 339-346.

[2] Bański, J. (2003). Selected aspects of present-day changes in Polish rural space. Geographia Polonica 76(1), 73-96.

[3] Bendyk, E. (2017). Wieś wygrywa z miastem? Polityka, October 24, 2017.

[4] Bonfiglio, A., Camaioni, B., Coderoni, S., Esposti, R., Pagliacci, F. \& Sotte, F. (2017). Are rural regions prioritizing knowledge transfer and innovation? Evidence from Rural Development Policy expenditure across the EU space, Journal of Rural Studies, 54, 78-87. DOI: 10.1016/j.jrurstud.2017.05.005.

[5] Bryder, J. \& Fuller, T. (1988). Pluriactivity as a rural development option. Oxford: The Arkleton Trust (Research) Ltd.

[6] Bukraba-Rylska, I. (2008). Socjologia wsi polskiej. Warszawa: Wydawnictwo naukowe PWN.

[7] Chmieliński, P. (2013). Ludność wiejska na rynku pracy. Zarobkowanie, bezrobocie, przedsiębiorczość i praca za granicą ludności wiejskiej w latach 2005-2011. Warszawa: Institute of Agricultural and Food Economics.

[8] Dudek, M. (2013). Określenie roli kapitału ludzkiego w rozwoju obszarów wiejskich. Warszawa: Instytut Ekonomiki Rolnictwa i Gospodarki Żywności.

[9] Durand, G. \& van Huylenbroeck, G. (2003). Multifunctionality and rural development: general framework. In: van Huylenbroeck, G. \& Durand, G., eds., Multifunctional Agriculture. A new paradigm for European Agriculture and Rural development (pp. 1-16). Farnham: Asgate Publishing Company.

[10] Evans, R. \& Papageorgiou, F. (2009). The Role of Education and Lifelong Learning in Sustainable Rural Development - Thematic Guide Five. Athens: Euracademy Association.

[11] Floriańczyk, Z., Janc, K. \& Czapiewski, K. (2012). The importance and diffusion of knowledge in the agricultural sector: The Polish experiences. Geographia Polonica, 83(1), 45-46. DOI: 10.7163/Gpol.2012.1.4.

[12] Frączek, P. (2018). Edukacja formalna i pozaformalna w procesie profesjonalizacji pracowników socjalnych. Edukacja - Technika - Informatyka, 9(3), 103-113. DOI: 10.15584/eti.2018.3.13. 
[13] Gabińska, C. G. (2016). Uwarunkowania rozwoju kapitału ludzkiego na obszarach wiejskich województwa podlaskiego. Przedsiębiorczość Edukacja, 12, 52-67. DOI: 10.24917/3136.

[14] Głębocka, K. (2015). The importance of lifelong learning in XXI century. Central European Review of Economics and Finance, 8(2), 51-62.

[15] Goszczyński, W., Kamiński, R. \& Knieć, W. (2013). Dylematy linoskoczka - czyli o profesjonalizacji autentyczności i perspektywach rozwoju organizacji pozarządowych na wsi i w małych miastach. Warszawa: FAPA.

[16] Hałasiewicz, A. \& Kaleta, A. (2000). Przedsiębiorczość na obszarach wiejskich. Warszawa: FAPA.

[17] Bański, J. (2010). Atlas Rolnictwa Polski. Warszawa: Instytut Geografii i Przestrzennego Zagospodarowania PAN.

[18] Janc, K. \& Czapiewski, K. (2016). Poziom wykształcenia rolników w Polsce - analiza czasowo-przestrzenna, Biuletyn Komitetu Przestrzennego Zagospodarowania Kraju PAN, 263, 9-28.

[19] Jaworski, P., Miszke, T., Wieczorkowski, R., Wiktor, M. \& Żochowska, A. (2018). Kształcenie dorosłych w 2016. Gdańsk: Urząd Statystyczny w Gdańsku.

[20] Jervell Moxnes, A. (1999). Changing patterns of family farming and pluriactivity. Sociologia Ruralis 39(1), 110-116. DOI: 10.1111/1467-9523.00095.

[21] Jin, Y. (2015). Recognition, validation and accreditation of non-formal and informal learning in UNESCO member state. Hamburg: UNESCO Institute for Lifelong Learning.

[22] Kamiński, R. (2011). Reorientacja zawodowa rolników - Konieczny kierunek zmian strukturalnych na wsi. Warszawa: Kancelaria Prezydenta Rzeczypospolitej Polskiej.

[23] Kamiński, R. (2015). Reorientacja zawodowa rolników i członków ich rodzin. Wieś i Rolnictwo, 166(1), 167-186.

[24] Kamiński, R. \& Sass, R. (2013). Vocational reorientation of farmers and members of their families - a new challenge for a rural Poland. In 19th International Farm Management Congress, SGGW, Warsaw, Poland. Warszawa: Warsaw University of Life Sciences.

[25] Kamiński, R. \& Sass. R. (2014). Reorientacja zawodowa rolników i domowników w województwie kujawsko - pomorskim, nowe wyzwanie dla doradztwa rolniczego. Zagadnienia Doradztwa Rolniczego, 75(1), 5-21.

[26] Kania, J., Dryas, M., Kutkowska, B. \& Kalinowski, J. (2011). System transferu wiedzy dla sektora rolno-spożywczego - oczekiwane kierunki rozwoju, Polish Journal of Agronomy 7 , 22-28.

[27] Kinsella, J., Wilson, S., de Jong, F. \& Renting, H. (2000). Pluriactivity as a Livelihood Strategy in Irish Farm Households and its Role in Rural Development. Sociologia Ruralis, 40(4), 481496. DOI: 10.1111/1467-9523.00162.

[28] Knieć, W. (2012). Wspólna Polityka Rolna a Zrównoważony Rozwój Obszarów Wiejskich Polski. Toruń: Wydawnictwo Uniwersytetu Mikołaja Kopernika.

[29] Knieć, W. (2018). Polityka szkoleniowa przedsiębiorców a zapotrzebowanie na kwalifikacje - raport badawczy dla WUP w Toruniu. Toruń: Pracownia Sztuk Plastycznych Sp. z o.o.

[30] Knieć, W. \& Strag, W. (2003). Potrzeby edukacyjne rolników z woj. Kujawsko-pomorskiego w kontekście integracji z Unią Europejską. Przysiek: Wydawnictwo RCRRiOW w Przysieku.

[31] Knieć, W., Goszczyński, W. \& Obracht-Prondzyński, C. (2013). Kapitał społeczny wsi pomorskiej. Wieżyca: Kaszubski Uniwersytet Ludowy.

[32] Knieć, W. \& Pluskota, A. (2018). Przyczyny trudnej sytuacji na rynku pracy na obszarach wiejskich południowej części regionu kujawsko-pomorskiego. Toruń: Wydawnictwo WUP. 
[33] Kulej-Dudek, E. \& Wiśniewska-Sałek, A. (2016). Transfer of information, knowledge and innovations in rural areas. Zeszyty Naukowe Politechniki Częstochowskiej: Zarządzanie, 21, 159-169.

[34] Lundvall, B. (1996). The Social Dimension of the Learning Economy. Aalborg University.

[35] Markowska, M., Klatta, P., Danielewicz, M. \& Stankowska, J. (2019). Analysis of competences in the agricultural sector [research report]. Warsaw: The Educational Research Institute (IBE).

[36] Matusiak, A. (2014). Uznawanie kwalifikacji w kontekście uczenia się przez całe życie. Ustalenia - doświadczenia - dylematy, Dyskursy Młodych Andragogów, 15, 63-74.

[37] McHenry, J. (2002). Management of knowledge in practice, learning to visualise competence [PhD Didissertation]. Sandvika: Norwegian School of Management.

[38] Mijal, A. (2017). Determinants of educational advancement of rural areas in Poland. Journal of Agribusiness and Rural Development, 43(1), 133-142. DOI: 10.17306/J.JARD.2017.00325.

[39] Mossakowska, E. \& Zawojska, A. (2009). Rozwój gospodarczy a kapitał ludzki na terenach wiejskich w Polsce, Zeszyty Naukowe Szkoły Głównej Gospodarstwa Wiejskiego w Warszawie Ekonomika i Organizacja Gospodarki Żywnościowej, 79, 5-21.

[40] Nadobnik, B. (2011). Nowoczesna wieś: po pierwsze edukacja. Warszawa: Instytut Obywatelski.

[41] Nowak, A. (2006). Bariery dostępu do edukacji ludności wiejskiej a reforma edukacji. Nierówności Społeczne a Wzrost Gospodarczy, 9, 459-469.

[42] Pateman, T. (2011). Rural and urban areas: comparing lives using rural/urban classification. Regional Trends, 43(1), 11-86. DOI: 10.1057/rt.2011.2.

[43] Renting, H., Oostindie, H., Laurent, C., Brunori, G., Barjolle, D., Jervell, A. M., Granberg, L., \& Heinonen, M. (2008). Multifunctionality of agricultural activities, changing rural identities and new institutional arrangements. International Journal of Agricultural Resources, Governance and Ecology, 7(4), 361-385.

[44] Rogers, E. M. (1988). Social Change in Rural Societies. New Jersey: Prentice Hall.

[45] Sawicka, J. (2002). The role of rural women in agriculture and rural development in Poland. Electronic Journal of Polish Agricultural Universities, 4(2), art. 1.

[46] Stefanel, M. R., Manole, A. M. \& Militaru, M. (2012). Lifelong learning - a way to reduce developments gaps between rural and urban areas. Procedia Social and Behavioral Science, 46, 4508-4512. DOI: 10.1016/j.sbspro.2012.06.286.

[47] Werquin, P. (2010). Recognising non-formal and informal learning: outcomes, policies and practices. Paris: OECD Publishing.

[48] Wojciuk, K. (2009). Na wsi odnowa. Nowa perspektywa. Poznań: Wiełkopolskie Stowarzyszenia Sołtysów.

[49] Woolcock, M. \& Narayan, D. (1999). Social capital: implications for Development Theory, Research and Policy. World Bank Research Observer, 15(2), 225-249. DOI: 10.1093/wbro/15.2.225.

[50] Wójcik, M. (2008). Przemiany społeczno-gospodarcze wsi aglomeracji łódzkiej w okresie transformacji ustrojowej. Łódź: Wydawnictwo Uniwersytetu Łódzkiego.

[51] Wójcik, M. (2017). Wiedza jako zasób lokalny w środowisku społecznym wsi. Przypadek rodzin rolniczych. Studia Obszarów Wiejskich, 45, 159-169. 
[52] A study by the Labor Market Department of the Ministry of Labor and Social Policy of 2009 entitled Stan i struktura rejestrowego bezrobocia na wsi w 2008 roku.

[53] CDR (2014). Transfer wiedzy i innowacji z nauki do rolnictwa w ocenie doradców rolnych na podstawie wyników badania sondażowego. Kraków: CDR w Brwinowie Oddział w Krakowie.

[54] The European Committee of the Regions (2014). Opinia Komitetu Regionów - Uznawanie umiejętności i kompetencji nabytych w ramach pozaformalnego i nieformalnego uczenia się (sprawozdawca Marek Olszewski), 2015/C 019/16. 